\title{
₹USGS
}

science for a changing world

Studies by the U.S. Geological Survey in Alaska, 2007

\section{Late Glacial-Holocene Pollen-Based Vegetation History from Pass Lake, Prince of Wales Island, Southeastern Alaska}

Professional Paper 1760-G

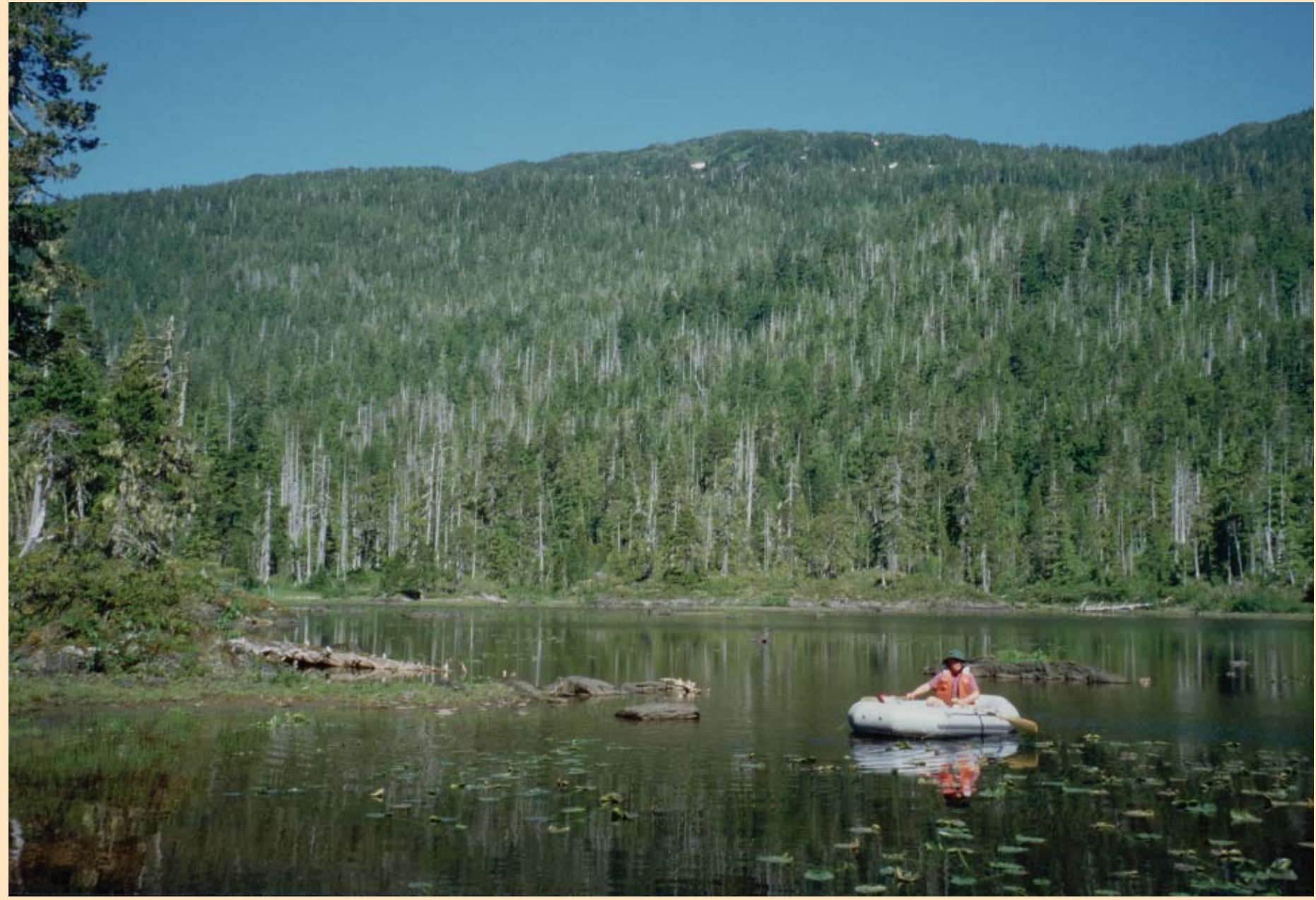

U.S. Department of the Interior

U.S. Geological Survey 
This page intentionally left blank 
Studies by the U.S. Geological Survey in Alaska, 2007

\section{Late Glacial-Holocene Pollen-Based Vegetation History from Pass Lake, Prince of Wales Island, Southeastern Alaska}

By Thomas A. Ager and Joseph G. Rosenbaum

Professional Paper 1760-G

U.S. Department of the Interior

U.S. Geological Survey 


\title{
U.S. Department of the Interior KEN SALAZAR, Secretary
}

\author{
U.S. Geological Survey \\ Marcia K. McNutt, Director
}

U.S. Geological Survey, Reston, Virginia: 2009

This report and any updates to it are available online at: http://pubs.usgs.gov/pp/1760/g/

For more information about the USGS and its products:

Telephone: 1-888-ASK-USGS (1-888-275-8747)

World Wide Web: http://www.usgs.gov/

Any use of trade, product, or firm names in this publication is for descriptive purposes only and does not imply endorsement by the U.S. Government.

Although this report is in the public domain, it may contain copyrighted materials that are noted in the text. Permission to reproduce those items must be secured from the individual copyright owners.

Produced in the Western Region, Menlo Park, California

Manuscript approved for publication, November 27, 2009

Text edited by Tracey Suzuki

Layout and design by Stephen L. Scott

Suggested citation:

Ager, T.A., and Rosenbaum, J.G., 2009, Late glacial-Holocene pollen-based vegetation history from Pass Lake, Prince of Wales Island, southeastern Alaska, in Haeussler, P.J., and Galloway, J.P., eds., Studies by the U.S. Geological Survey in Alaska, 2007: U.S. Geological Survey Professional Paper 1760-G, 19 p.

\section{FRONT COVER}

Photograph of Pass Lake area and adjacent forest vegetation, as seen from the southern shore, south-central Prince of Wales Island, Alaska. (USGS photograph by Thomas Ager.) 


\section{Contents}

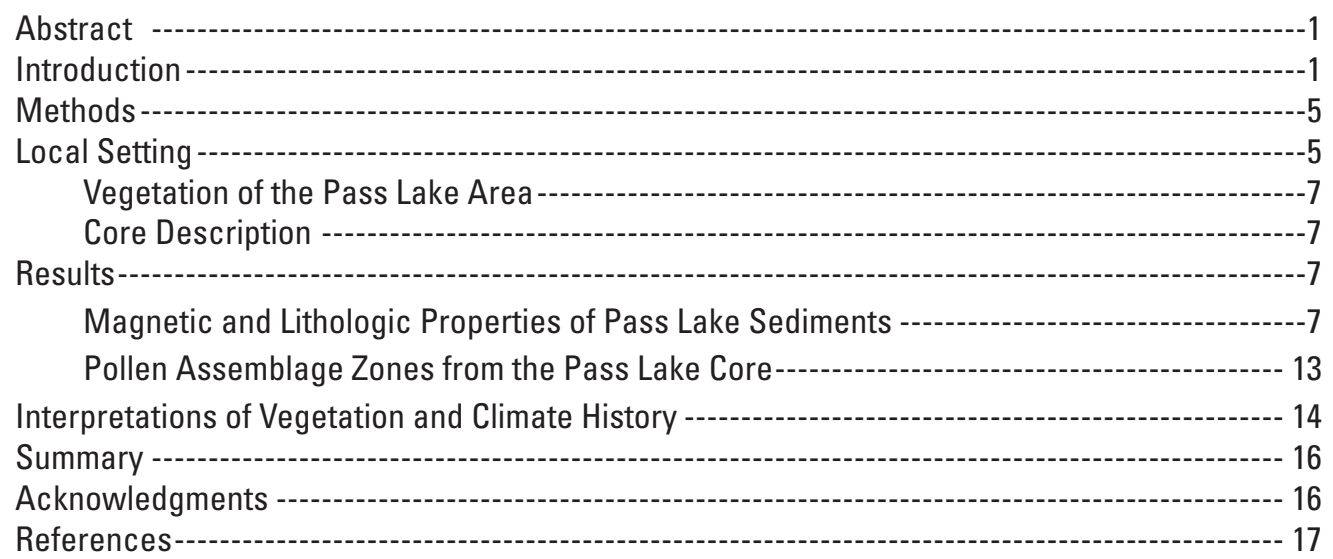

\section{Figures}

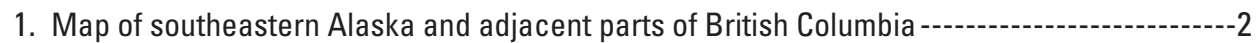

2. Map of southern southeastern Alaska showing Prince of Wales Island------------------------3

3. Map of Pass Lake area, south-central Prince of Wales Island, Alaska -----------------------6

4. Photograph of Pass Lake area and adjacent forest vegetation ------------------------------8

5. Lithological description of the peat and sediment core from Pass Lake ------------------------9

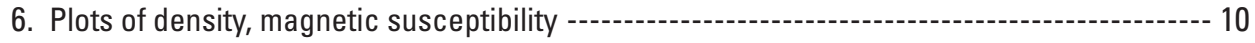

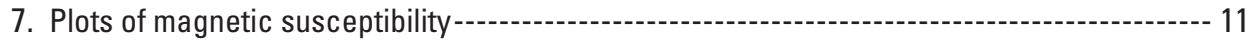

8. Plots of density, magnetic susceptibility ------on 12

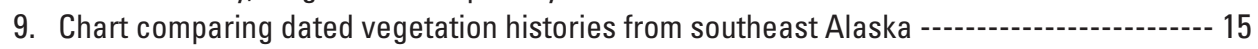

\section{Tables}

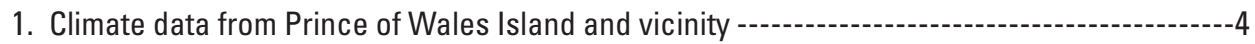

2. Radiocarbon and calibrated ages from the Pass Lake core -------------------------- 10 
This page intentionally left blank 


\title{
Late Glacial-Holocene Pollen-Based Vegetation History from Pass Lake, Prince of Wales Island, Southeastern Alaska
}

\author{
By Thomas A. Ager and Joseph G. Rosenbaum
}

\section{Abstract}

A radiocarbon-dated history of vegetation development since late Wisconsin deglaciation has been reconstructed from pollen evidence preserved in a sediment core from Pass Lake on Prince of Wales Island, southeastern Alaska. The shallow lake is in the south-central part of the island and occupies a low pass that was filled by glacial ice of local origin during the late Wisconsin glaciation. The oldest pollen assemblages indicate that pine woodland (Pinus contorta) had developed in the area by $\sim 13,715 \mathrm{cal}$ yr B.P. An abrupt decline in the pine population, coinciding with expansion of alder (Alnus) and ferns (mostly Polypodiaceae) began $\sim 12,875$ yr B.P., and may have been a response to colder, drier climates during the Younger Dryas climatic interval. Mountain hemlock (Tsuga mertensiana) began to colonize central Prince of Wales Island by $\sim 11,920$ yr B.P. and was soon followed by Sitka spruce (Picea sitchensis). Pollen of western hemlock (Tsuga heterophylla) began to appear in Pass Lake sediments soon after 11,200 yr B.P. The abundance of western hemlock pollen in the Pass Lake core during most of the Holocene appears to be the result of wind transport from trees growing at lower altitudes on the island. The late Holocene pollen record from Pass Lake is incomplete because of one or more unconformities, but the available record suggests that a vegetation change occurred during the late Holocene. Increases in pollen percentages of pine, cedar (probably yellow cedar, Chamaecyparis nootkatensis), and heaths (Ericales) suggest an expansion of muskeg vegetation occurred in the area during the late Holocene. This vegetation change may be related to the onset of cooler, wetter climates that began as early as $\sim 3,774$ yr B.P. in the region. This vegetation history provides the first radiocarbon-dated Late Glacial-Holocene terrestrial paleoecological framework for Prince of Wales Island. An analysis of magnetic properties of core sediments from Pass Lake suggests that unconformities caused by low lake levels may be detectable where finegrained ferrimagnets are concentrated in peaty sediments.

\section{Introduction}

This paper presents the results of an investigation of past vegetation and climates of the Pass Lake area of Prince of
Wales Island in the southern Alexander Archipelago (figs. 1 and 2). Prince of Wales Island is the largest island in southeast Alaska, and the second largest island in Alaska, after Kodiak Island. The island has an area of $6,730 \mathrm{~km}^{2}$ and is rimmed by a rocky coastline, deeply indented by numerous fiords and embayments. Much of the the island is mountainous and displays abundant evidence of landscape modification by past glaciations, such as U-shaped valleys, hanging valleys, arêtes, abandoned cirques, and extensive deposits of glacial till. The highest peaks on the island are about $1,000 \mathrm{~m}$ or lower. Modern glaciation level is estimated to be about $1,100 \mathrm{~m}$ for the area (Østrem and others, 1981), therefore, no glaciers exist on the island at present, in contrast to the higher alpine glacier-mantled peaks and ridges on Baranof, Chichagof, and Admiralty Islands in the northern Alexander Archipelago, and the extensive icefields that exist in the Coast Mountains to the east.

The Prince of Wales Island area has a cool, temperate, wet maritime climate (fig. 2; table 1). There is no dry season, but the heaviest precipitation occurs in autumn and winter. Although most of the annual precipitation is in the form of rain and fog at lower altitudes, snowstorms do occur at sea level during the winter.

The vascular plants of this area of Alaska are described in floras by Hultén (1968) and Pojar and McKinnon (1994). Taxonomy of plants discussed in this paper generally follows Pojar and McKinnon (1994). The alpine flora of Prince of Wales Island is described by Jaques (1973). Muller (1982) lists 868 species, subspecies, and varieties of native vascular plants known to grow in southeastern Alaska. Many of those taxa occur on Prince of Wales Island, but no master list of species has been compiled for the island.

Vegetation communities in southern southeastern Alaska have been described by DeMeo and others (1992), Viereck and Little (1972), and Alaback and Pojar (1997). For the purposes of this paper we define southern southeastern Alaska as the islands and Coast Mountains south of Admiralty Island, extending south to Dixon Entrance (figs. 1 and 2).

Most of Prince of Wales Island is mantled with dense, coastal rainforests of Tsuga heterophylla (western hemlock), Picea sitchensis (Sitka spruce), Thuja plicata (red cedar), Tsuga mertensiana (mountain hemlock), and Chamaecyparis nootkatensis (yellow cedar). Pinus contorta, ssp. contorta (shore pine) also is common on the island, particularly in 


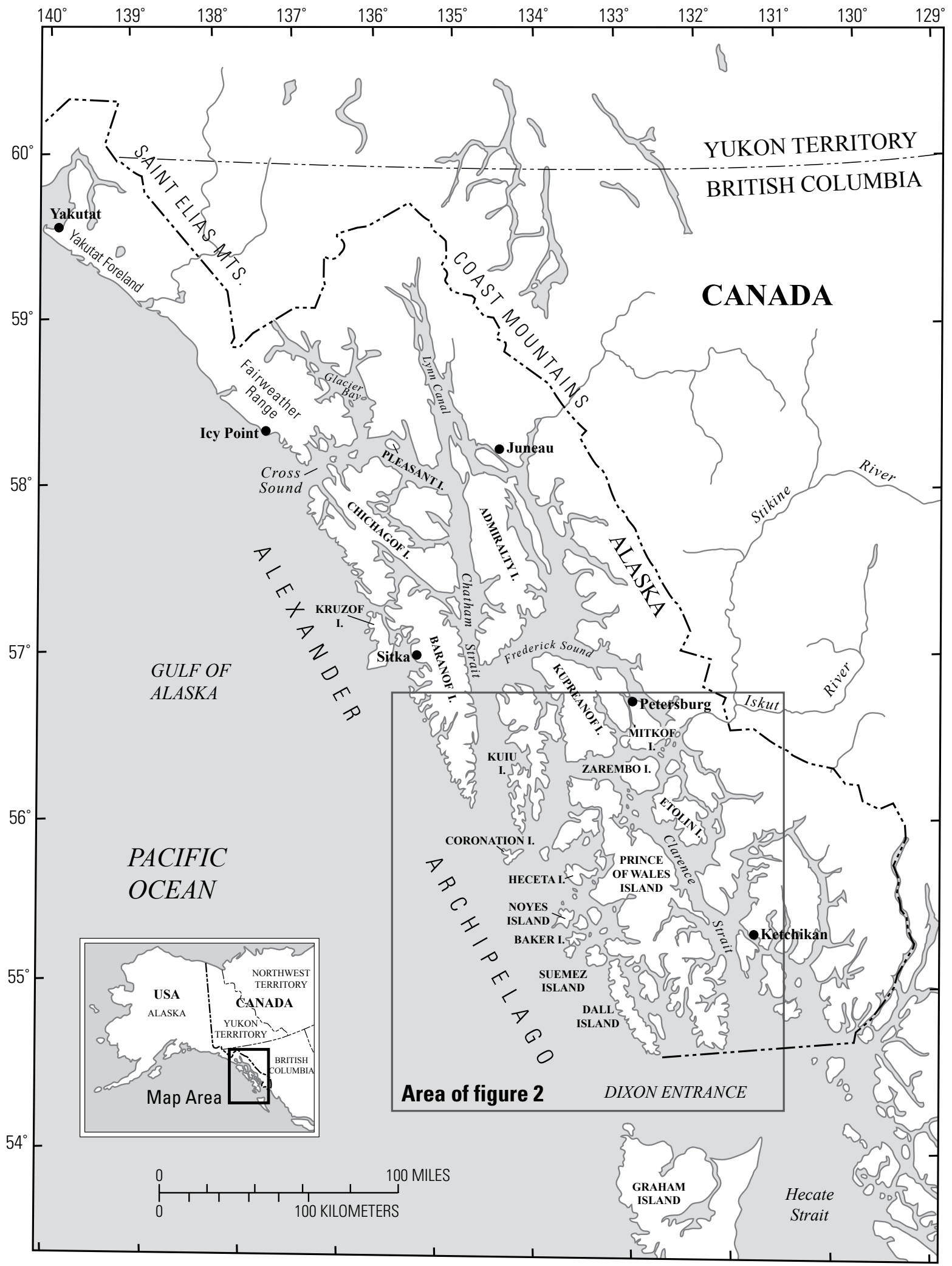

Figure 1. Map of southeastern Alaska and adjacent parts of British Columbia, including the northern Queen Charlotte Islands. Pass Lake, the research site discussed in this paper, is located on south-central Prince of Wales Island within the southern Alexander Archipelago. Also shown is Pleasant Island, where one of the few well-documented and adequately dated pollen records from southeastern Alaska was obtained (Hansen and Engstrom, 1996). 


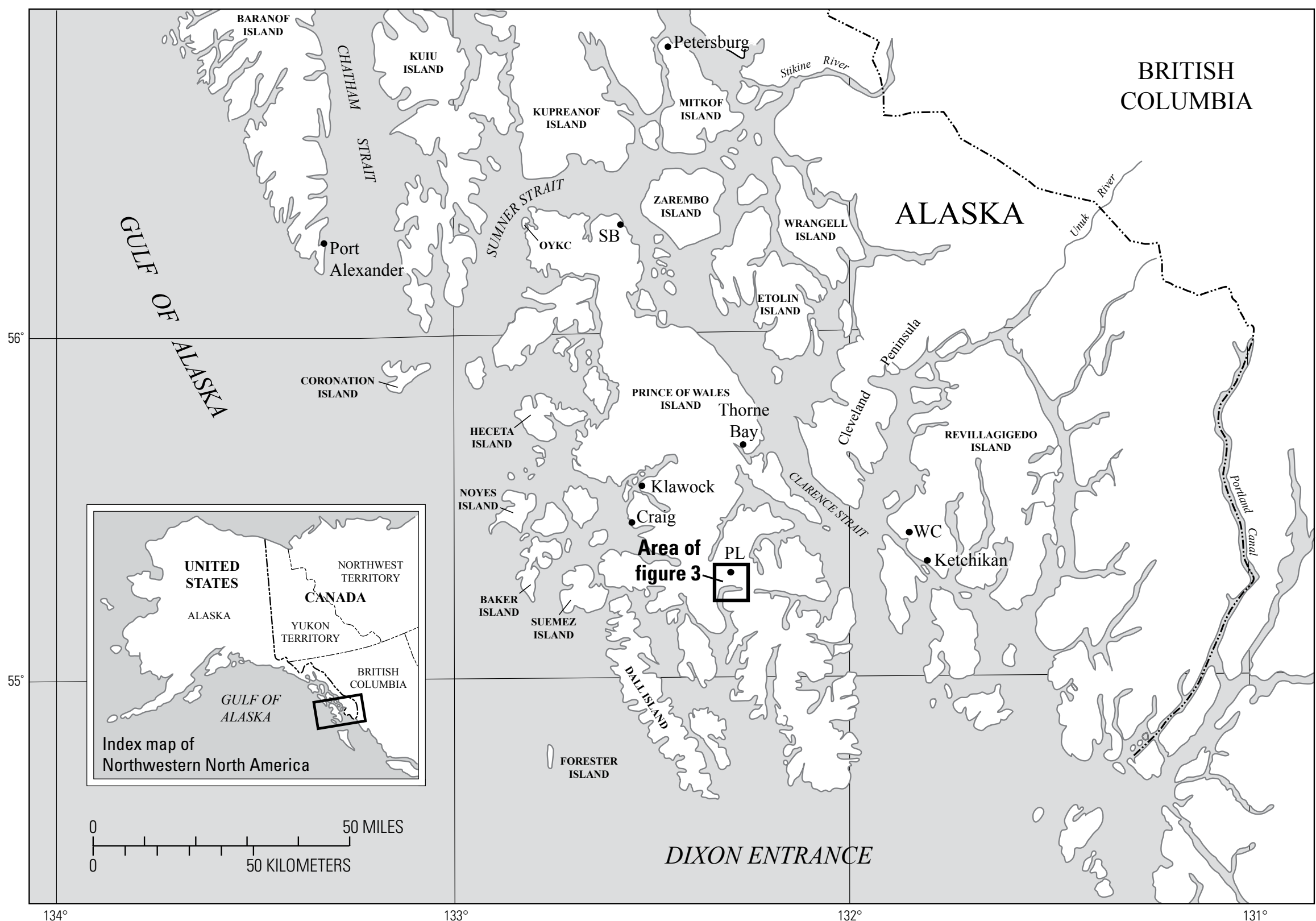

Figure 2. Map of southern southeastern Alaska showing Prince of Wales Island and vicinity and locations of climate-data stations at Petersburg (Mitkof Island), Ketchikan (Revillagigedo Island), Klawock (Prince of Wales Island), and Port Alexander (Baranof Island) (table 1). Also shown are locations of pollen records from the region that are discussed in this paper: (1) Pass Lake, PL (central Prince of Wales Island); (2) Salmon Bay, SB (northeast Prince of Wales Island; Heusser, 1960); (3) Ward Creek, WC (near Ketchikan; Heusser, 1952, 1965, 1985); (4) Petersburg area (Mitkof Island; Heusser, 1952). Note also the location of On Your Knees Cave (OYKC; northwestern Prince of Wales Island). 
Table 1. Climate data from Prince of Wales Island and vicinity, southern southeast Alaska.

[See figure 2 for locations of climate data collection stations].

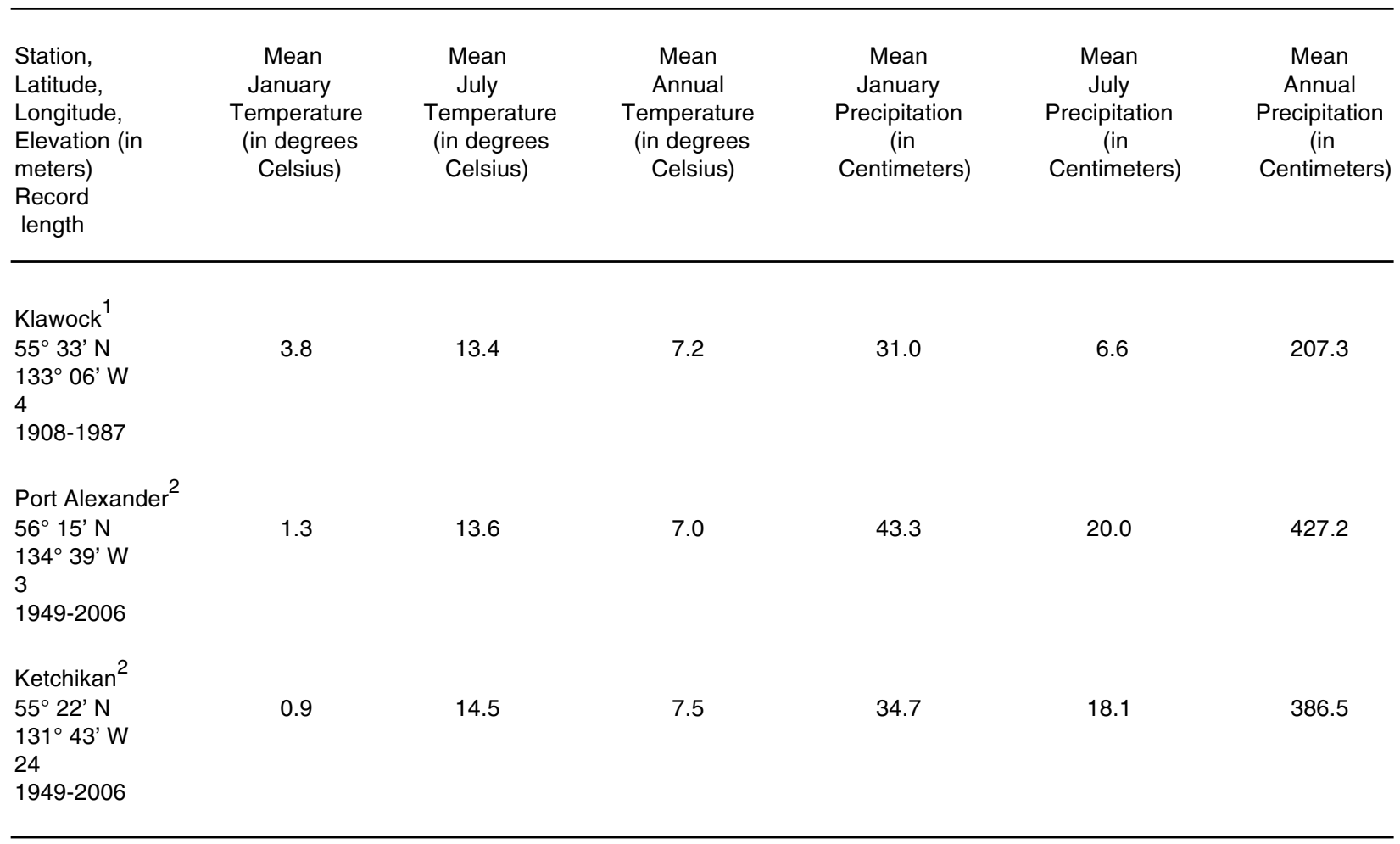

${ }^{1}$ Leslie, 1989.

${ }^{2}$ Climate data available online at http://www.dri.edu/index.html (last accessed September 23, 2009).

muskegs (unforested or sparsely forested peatlands), on coastal rock outcrops, and in the lower subalpine zone on plateaus and ridges. There are also scattered populations of subalpine fir (Abies lasiocarpa) on ridges and peaks in the central and northwestern part of the island (Harris, 1969; Worley and Jaques, 1973).

Muskeg vegetation occurs over large areas of Prince of Wales Island, mostly in flat areas or on gentle slopes, particularly if there is impermeable bedrock or glacial deposits forming the substrate. Such poorly drained areas are characterized by thick, wet, peaty soils (Histosols) composed largely of the remains of sedges, mosses, and heaths. Peat deposits and the floristic composition of muskeg vegetation in southern southeastern Alaska were described by Dachnowski-Stokes (1941) as part of an early assessment of peat resources of Alaska. The ecology of muskeg vegetation in southeastern Alaska is discussed by Neiland (1971).

Glacial history of southern southeastern Alaska has not been studied in detail compared with adjacent coastal British Columbia, or south-central Alaska such as Cook Inlet, where studies of glacial history have been underway for several decades (for example, Karlstrom, 1964; Schmoll and others,
1999; Reger and others, 2007). Mann (1986) summarized the knowledge of southeastern Alaska glacial history up to the mid-1980s. His review reveals the paucity of published information available on late Wisconsin glacial history of southern southeast Alaska. In the two decades since Mann's review was written, some reconnaissance studies and observations on evidence of past glacial activity have been published for the region, but details are still lacking (Dixon and others, 1997; Carrara and others, 2003, 2007; Baichtal and others, 1997; Nowacki and others, 2001; Kaufman and Manley, 2004).

The research on late Quaternary deposits conducted by the U.S. Geological Survey (USGS) in southeastern Alaska during the past decade has been motivated in part by the need for paleoenvironmental data for this region. Numerous archeological sites have been documented in southeastern Alaska, ranging in age from historical sites to the early Holocene or slightly earlier ( $\geq 11,440$ yr B.P.; Ackerman, 1996; Dixon, 1999; Davis, 1966). In the southern Alexander Archipelago, the Chuck Lake site on Heceta Island (fig. 2) has archeological evidence from a shell midden dating to $\sim 9,145 \mathrm{yr}$ B.P.). Other archeological evidence from Heceta Island suggests human occupation on that island by $\sim 10,190$ yr B.P.; Ackerman, 1996; 
Dixon, 1999). Recent archeological discoveries at On Your Knees Cave, on northwestern Prince of Wales Island (OYKC, fig. 2) suggest that humans may have visited the cave as early as $\sim 12,270$ yr B.P.; Dixon, 1999, 2001). Skeletal elements of a human male were found in OnYour Knees Cave by T. Heaton in 1996 (Heaton and Grady, 2003; Dixon, 1999, 2001). Radiocarbon dates on the human bone material, corrected for marine-reservoir effect, indicate that the individual lived $\sim 9,200{ }^{14} \mathrm{C}$ yr B.P. $(\sim 10,340$ yr B.P.; Heaton and Grady, 2003; Dixon, 1999; Dixon and others, 1997).

Vertebrate faunas from On Your Knees Cave and numerous other caves in southeastern Alaska provide a history of numerous marine and terrestrial mammal, fish, and bird species throughout most of the past $\sim 45,000$ years (Heaton and others, 1996; Heaton and Grady, 2003). Faunal changes appear to reflect regional climatic and ecological changes during that time. These recent archeological and vertebratefossil discoveries in the region created a need for well-documented, radiocarbon-dated histories of the late Quaternary vegetation history of the region, and specifically for Prince of Wales Island, in order to provide a terrestrial ecological context in which to interpret the cultural and fossil evidence.

Another motivation for studying the vegetation history of this region since deglaciation is the need to understand vegetation dynamics over a relatively long time interval to better anticipate how coastal terrestrial ecosystems respond to changes in climate. It also is useful to understand how long it takes a complex coastal-forest ecosystem to develop after a major regional disturbance, such as the last glaciation that covered most of the landscape with ice during the late Wisconsin glacial interval.

Pioneering research on late Quaternary vegetation history in southern southeastern Alaska was conducted by Calvin Heusser $(1952,1960,1965,1985)$. Heusser cored peat deposits for pollen analysis at four coastal sites on Prince of Wales Island: Salmon Bay on the northeastern coast; Sarkar Lake on the northwestern coast; near Hollis on the central east coast; and Kendrick Bay on the southern coast. Only one of those sites (Salmon Bay (SB) fig. 2) appears to have penetrated preHolocene deposits, based on comparisons of pollen profiles with dated records from the region (discussed below). Heusser also described several pollen records from peat deposits from Ward Creek near Ketchikan (fig. 2; Heusser, 1952, 1965, 1985) that are important for understanding the local sequence of postglacial vegetation changes. However, none of Heusser's sites from southeastern Alaska south of Juneau (fig. 1) have radiocarbon ages, so the chronology of vegetation changes at his sites in this region is unknown.

\section{Methods}

The peat and sediment core described in this paper was obtained from central Pass Lake at a site where the water depth was about 1 meter. A floating coring platform was anchored over the coring site. The sediment core was obtained by using a modified Livingstone piston corer. The core diameter is $5 \mathrm{~cm}$; core segments were obtained in drives of 1 $\mathrm{m}$ or less. Following the field season, the core segments were measured, described, and sampled for pollen analysis, radiocarbon dating, and studies of magnetic properties at the USGS laboratories in Denver, Colorado.

Samples for pollen analysis were taken at $5-\mathrm{cm}$ intervals and processed to concentrate pollen and spores by using maceration techniques modified from those described by Doher (1980). Slides of pollen residues were examined microscopically, generally at magnifications of $630 \mathrm{X}$, by using a Leitz Dialux microscope. At least 300 pollen grains, plus a highly variable quantity of spores, were identified and counted for each sample. Pollen identifications relied on modern reference slides of Alaskan and Pacific Northwest pollen and spore types in the collections of the U.S. Geological Survey and on published illustrations of pollen and spore types (Moriya, 1978). Interpretation of past vegetation types from pollen assemblages determined from analysis of the Pass Lake core was aided by comparisons with modern pollen assemblages analyzed in surface sediments from known vegetation types from numerous North Pacific coastal region locations (Peteet, 1986; Heusser, 1985).

Magnetic property measurements were conducted on 96 samples from the Pass Lake core. Wet sediment samples were placed in nonmagnetic $3.2-\mathrm{cm}^{3}$ plastic boxes. The sampling intervals for the magnetic specimens range from 1 to $6 \mathrm{~cm}$. Anhysteretic and isothermal remanent magnetizations (ARM and IRM) were measured with a high-speed spinner magnetometer. ARM was imparted by using an alternating field with a peak intensity of 100 milliTesla (mT) and a bias field of 0.1 mT. After measurement of ARM, IRM was first imparted in a 1.2 $\mathrm{T}$ field and then in the opposite direction in a field of $0.3 \mathrm{~T}$ $\left(\mathrm{IRM}_{-0.3 \mathrm{~T}}\right)$. Hard isothermal remanent magnetization (HIRM; see King and Channel, 1991) is given by

$$
\mathrm{HIRM}=\left(\mathrm{IRM}_{\mathrm{IR}} \mathrm{IR}_{-0.3 \mathrm{~T}}\right) / 2 .
$$

Samples were then dried and weighed. Dry bulk densities were calculated by dividing the dry mass of each sample by the standard volume of the sample boxes $\left(3.2 \mathrm{~cm}^{3}\right)$. Finally, magnetic susceptibility $(\chi)$ was measured in a 600 -Hertz alternating field with an amplitude of about $0.1 \mathrm{mT}$. All magnetic properties are given in SI mass units based on the dry sample masses.

\section{Local Setting}

Pass Lake is in a low mountain pass (altitude $364 \mathrm{~m}$ ) separating two east-west trending drainages in the south-central area of the island in the Craig (B-2) USGS topographic map at $55^{\circ} 19.66^{\prime} \mathrm{N}, 132^{\circ} 36.39^{\prime} \mathrm{W}$ (figs. 2 and 3). The lake is shallow, generally 1-2 m deep, and has an area of about 9 ha. It is accessable by Forest Service logging road 21 that connects to roads from the Klawock-Craig area on the west-central coast 


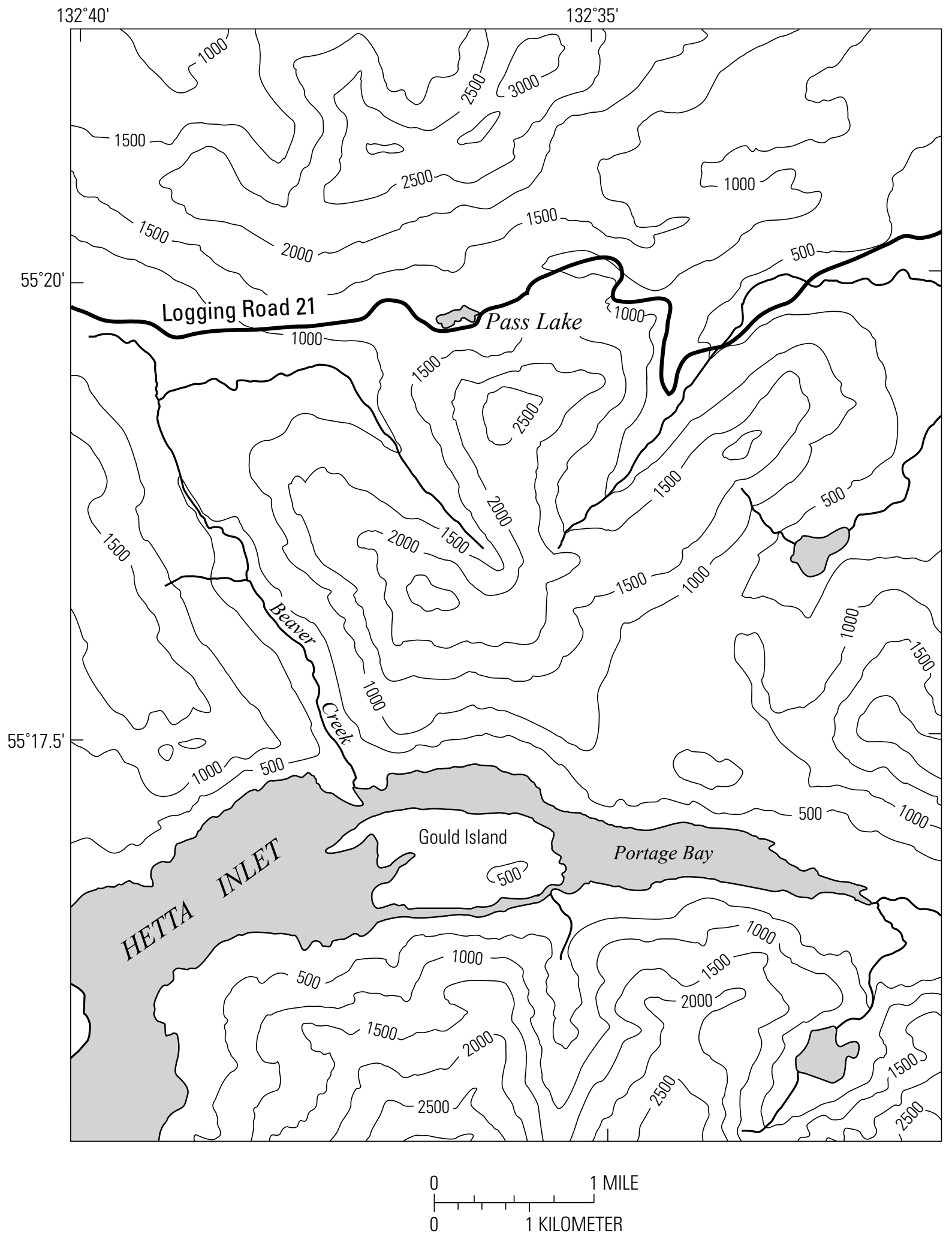

Figure 3. Map of Pass Lake area, south-central Prince of Wales Island, Alaska. This area of Prince of Wales Island has been extensively glaciated, apparently by local icecaps and alpine glaciers rather than by Cordilleran ice from the Coast Mountains on the mainland to the east. Contour interval 500 feet $(\sim 152 \mathrm{~m})$. 
of Prince of Wales Island (Fig.1). The lake floor generally is flat, but a meandering channel traverses the central part of the lake from west to east, suggesting that the present episode of higher lake level may have developed recently, possibly from construction of beaver dams. Evidence of abandoned shorelines at least $60 \mathrm{~cm}$ above the present lake level and beaver dams near the present lake outlet suggest that at least minor changes in water levels have occurred in the lake in the recent past. At least part of the lake floor may have been subaerially exposed in the past, but the presence of pollen of Nuphar (yellow pond-lily) throughout most of the core suggests that any such intervals of exposure were few. The channel meandering across what is presently the lake floor may have eroded away some of the accumulated peat and sediments in some parts of the lake basin. The coring site was located away from any known channels, past or present.

\section{Vegetation of the Pass Lake Area}

Present-day vegetation in the immediate vicinity of Pass Lake includes extensive muskeg (bogs, fens) mantling the valley floor, and montane conifer forest of Picea sitchensis and Tsuga mertensiana growing on the adjacent valley slopes (fig. 4). Stunted Pinus contorta subsp. contorta, Chamaecyparis nootkatensis, and Tsuga mertensiana trees are scattered widely across the poorly drained muskeg adjacent to the lake. Common shrubs and low, woody plants in the vicinity of the lake include Alnus crispa ssp. sinuata (Sitka alder), Oplopanax horridus (devil's club), Vaccinium ovalifolium (oval-leafed blueberry), V. caespitosum (dwarf blueberry), V. uliginosum (bog blueberry), V. vitis-idaea (lingonberry), Menziesia ferruginea (false azalea), Ledum groenlandicum (Labrador tea), Kalmia polifolia (western bog laurel), Andromeda polifolia (bog rosemary), Empetrum nigrum (crowberry), Cornus canadensis (bunchberry), and Sanguisorba canadensis (Canada burnet). Common herbaceous plants observed near the lake include Cyperaceae (sedges), such as Carex spp. and Eriophorum angustifolium, Fauria crista-galli (deer cabbage), Lisichiton americanum (skunk cabbage), Dodecatheon spp. (shooting star), Trientalis arctica (northern starflower), Valeriana sitchensis (Sitka valerian) and insectivorous bog plants such as Pinguicula vulgaris (common butterwort) and Drosera rotundifolia (round-leaved sundew). Aquatic plants observed growing in Pass Lake include Myriophyllum spp. (water-milfoil) and Nuphar polysepalum (yellow pond-lily).

\section{Core Description}

The Pass Lake core is $320 \mathrm{~cm}$ long (fig. 5). The upper 110 $\mathrm{cm}$ of the core consists of alternating layers of fine detrital peat and peaty silt and coarser textured layers of woody plant detritus. Radiocarbon ages and calibrated ages of organic material from the core (table 2) indicate that much, or possibly all, of this upper $110 \mathrm{~cm}$ of the core was deposited rapidly, perhaps within the past $\sim 1,600 \mathrm{yr}$ ), and possibly within just a few centuries $(\sim 1,600$ to $1,300 \mathrm{yr}$ B.P.). The coarser layers may have been deposited during heavy rainfall, or snowmeltwater flood events, when large volumes of plant detritus may have been carried in drainages from surrounding steep mountain slopes into the lake. Calibrated radiocarbon ages, changes in core lithology, magnetic properties, and pollen assemblages in the upper $150 \mathrm{~cm}$ of the core (discussed below) suggest that there is probably a significant unconformity at, or near, $110 \mathrm{~cm}$ depth in the core. From 110 to $163 \mathrm{~cm}$ depth in the core, the sediments consist of very dark gray to very dark brown peaty mud. From 163 to $190 \mathrm{~cm}$ the core sediments are very dark brown to very dark gray brown organic mud. From 190 to $270 \mathrm{~cm}$ the core sediments are dark gray brown to dark brown peaty mud. From 270 to $321 \mathrm{~cm}$, the core consists of laminated, greenish gray clayey mud. Pollen and spores were extracted successfully from all samples except those from mineral sediments in the lowermost $5 \mathrm{~cm}$ of the core.

\section{Results}

\section{Magnetic and Lithologic Properties of Pass Lake Sediments}

A study of magnetic properties of the Pass Lake core sediments was done in an effort to enhance the interpretation of the environmental history of the Pass Lake area by documenting intervals of greater magnetic-mineral sediment influx into the lake basin. Characteristics of lake sediments, including density and magnetic properties, vary with changes in the environment. Magnetic properties (which reflect the types, amounts, and grain sizes of magnetic minerals) may vary not only in response to changes in the concentration or source of detrital minerals but also due to processes within the lake that either destroy or form magnetic phases (Thompson and Oldfield, 1986; Verosub and Roberts, 1986; Evans and Heller, 2003). Magnetic susceptibility, ARM, and IRM commonly reflect the content of ferrimagnetic minerals (magnetite, titanomagnetite, and greigite), but differ in their sensitivity to variations in magnetic grain size (Dunlop and Ozdemir, 1997). Hard IRM (HIRM) is a measure of the highcoercivity minerals (hematite and goethite). For ferrimagnetic grains large enough to carry remanent magnetization $(\geq$ $0.03 \mu \mathrm{m}), \chi$ has a weak dependence on magnetic grain size, increasing somewhat as grains increase from single-domain to multidomain. For such remanence-carrying grains, both IRM and ARM decrease with increasing grain size so that large multidomain grains contribute relatively little in comparison to smaller grains. ARM varies more strongly for very small grains $(<1 \mu \mathrm{m})$ and is particularly strong for magnetite grains with diameters on the order of $0.1 \mu \mathrm{m}$ or smaller (Oldfield, 1994). Because of the differing dependence of those parameters on the size of ferrimagnetic grains, the ratio, $\chi_{\mathrm{ARM}} / \chi$ provides a convenient qualitative measure of "magnetic grain 


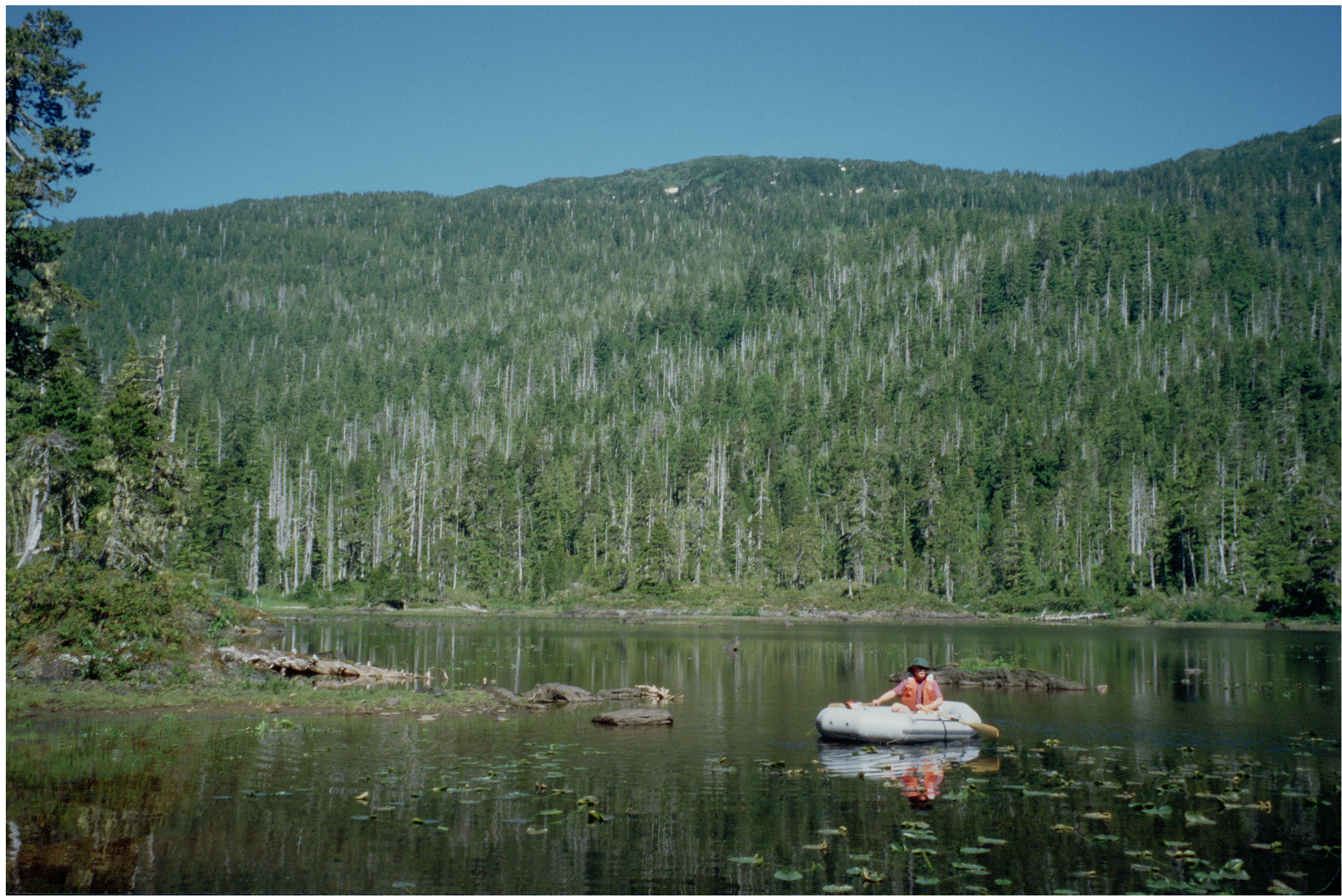

Figure 4. Photograph of Pass Lake area and adjacent forest vegetation, as seen from the southern shore, south-central Prince of Wales Island, Alaska. (USGS photograph by Thomas Ager, USGS.) 
size" (with higher values indicating finer sizes). (Note: The susceptibility of ARM, $\chi_{\text {ARM }}$, is ARM divided by the applied bias field.)

Variations in density with depth (fig. 6) reflect changes in the proportions of lithic material and organic matter. The largest change in sediment density occurs at a core depth of 270 $\mathrm{cm}$, where low-density organic-rich peaty mud overlies denser mineral-rich mud. Density then increases slightly to $190 \mathrm{~cm}$ before rising sharply. The sharp increase occurs at the contact between peaty mud and an overlying, mineral-rich silty clay. Density peaks at about $180 \mathrm{~cm}$ and then decreases gradually to the upper contact of silty clay. Above $160 \mathrm{~cm}$, densities in the

\section{Pass Lake, Prince of Wales Island}

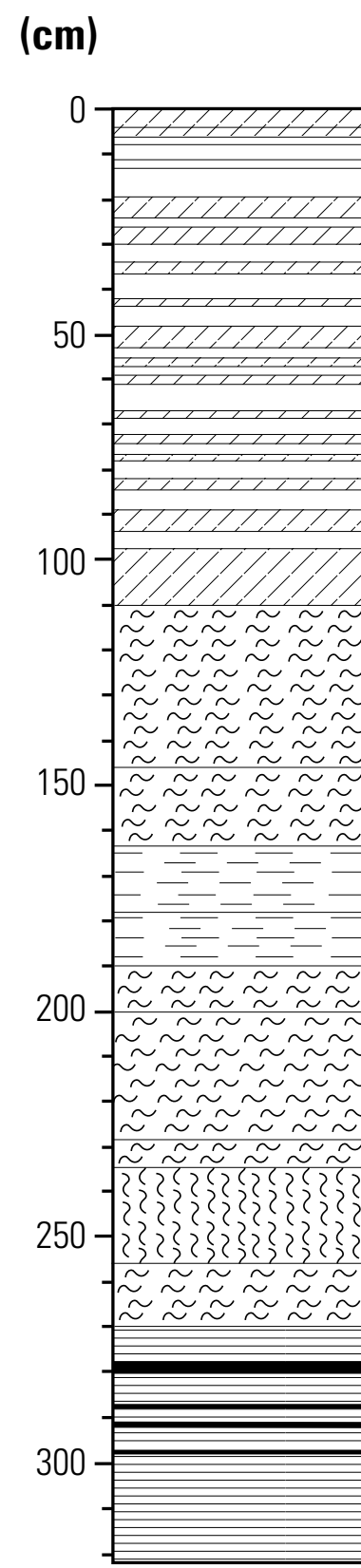

\section{Color}

10 yr $2 / 2$

very dark brown

10 yr $2 / 1-2 / 2$

black to very dark brown

10 yr $2 / 2$

very dark brown

10 yr $3 / 2$ very dark gray

10 yr $3 / 1$ very dark gray brown

2.5 yr $3 / 2$ very dark gray brown

$2.5 \mathrm{yr} 4 / 2$ dark gray brown

10 yr 2/2 very dark brown

10 yr $3 / 2$ very dark brown

10 yr 4/2 dark gray brown

10 yr 2/2 very dark brown

10 yr 3/2 dark brown

$5 \mathrm{~g} \mathrm{6/1}$ greenish gray

$5 \mathrm{~g}$ 4/1 dark greenish gray

$5 \mathrm{~g}$ 6/1 greenish gray

\section{Sediment Type}

Peaty silt

Cyclic peat beds-alternating fine peat and coarse peat with with needles, wood, bark

Peaty mud

Peaty mud

Mud

Mud

Silty clay, with faint laminations

Peaty mud

Peaty, mottled mud

Peaty mud

Peaty bioturbated mud

Peaty mud

Laminated mud (clay)

Laminated mud (clay) with four black laminations

Laminated mud (clay)

Figure 5. Lithological description of the peat and sediment core from Pass Lake, Prince of Wales Island, southeastern Alaska. 
Table 2. Radiocarbon and calibrated ages from the Pass Lake core, Prince of Wales Island, southeastern Alaska.

\begin{tabular}{lclccc}
\hline Sample ID & $\begin{array}{c}\text { Depth (in } \\
\text { centimeters) }\end{array}$ & Material & $\begin{array}{l}\text { 14C age } \\
\text { (yr BP) }\end{array}$ & $\begin{array}{c}\text { Lab } \\
\text { number }\end{array}$ & $\begin{array}{c}\text { Calibrated age } \\
\text { (yr BP) }\end{array}$ \\
\hline Pal-1 & 50 & Wood & $1530 \pm 40$ & WW3477 & $1413 \pm 49$ \\
Pal-2 & 100 & Wood & $1620 \pm 40$ & WW3478 & $1514 \pm 49$ \\
Pal-117 & 117 & Peat & $4295 \pm 45$ & WW5662 & $4852 \pm 31$ \\
Pal-3 & 126 & Hemlock cone & $4090 \pm 40$ & WW3479 & $4595 \pm 101$ \\
Pal-200 & 200 & Plant detritus & $6840 \pm 35$ & WW4390 & $7670 \pm 24$ \\
Pal-258 & 258 & Plant detritus & $9775 \pm 45$ & WW4398 & $11208 \pm 23$ \\
Pal-267 & 267 & Plant detritus & $3095 \pm 40$ & WW4399 & $3329 \pm 46^{2}$ \\
Pal-280 & 280 & Pollen & $10165 \pm 40$ & WW5143 & $11853 \pm 93$ \\
Pal-295 & 295 & Pollen & $10915 \pm 40$ & WW5148 & $12836 \pm 79$ \\
Pal-313 & 313 & Pollen & $11875 \pm 40$ & WW5149 & $13780 \pm 102$ \\
& & & & \\
\hline
\end{tabular}

${ }^{1}$ Radiocarbon calibration data available online at http://www.radiocarbon.LDEO.columbia.edu last accessed on September 6, 2009. See Fairbanks and others, 2005.

${ }^{2}$ Sample QQ 4399 from core depth 267 was apparently contaminated with early Holocene plant material during piston coring operations, and the resulting young age for the sample is rejected for interpreting the chronology of the core.

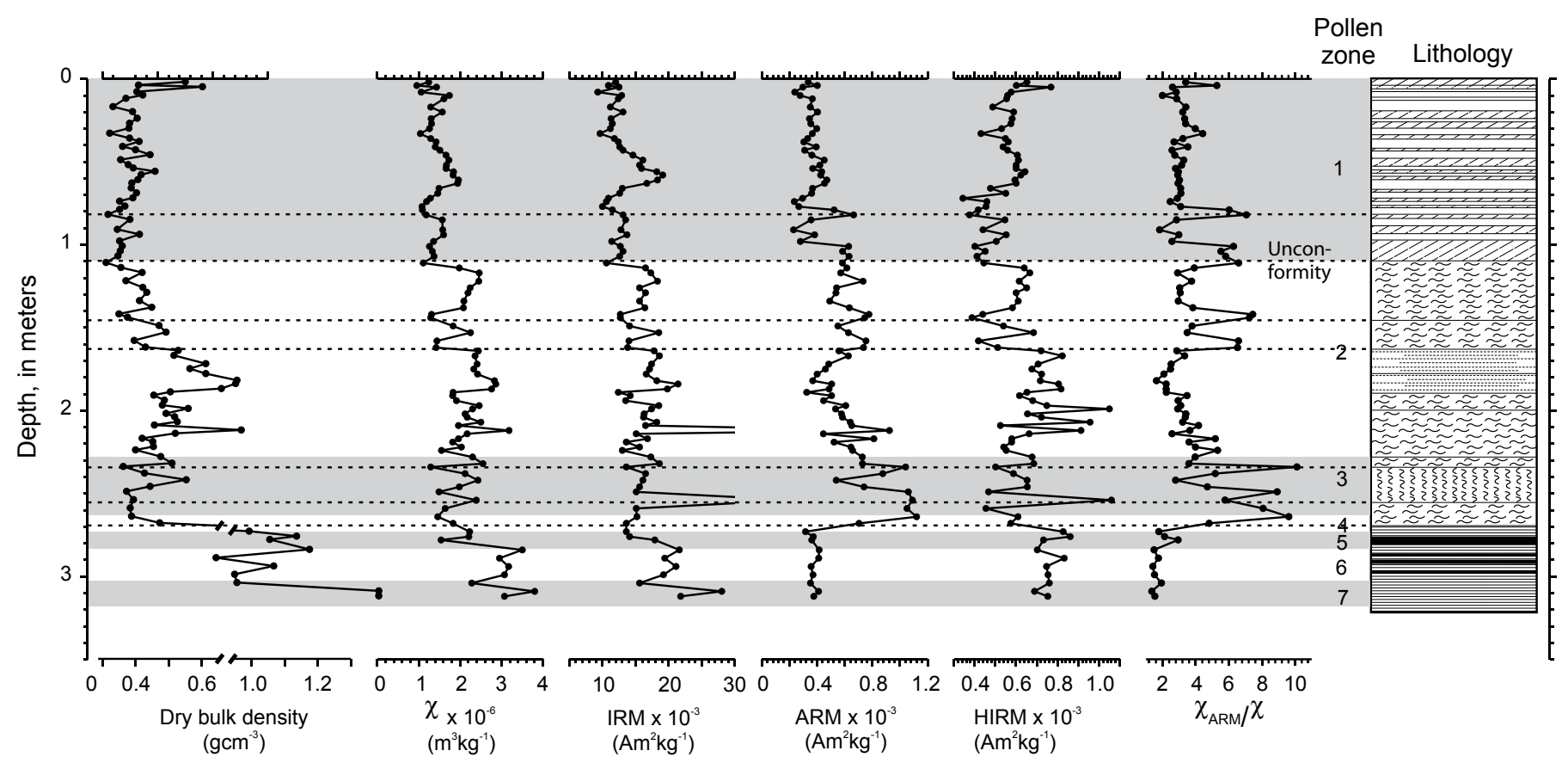

Figure 6. Plots of density, magnetic susceptibility $(\chi)$, isothermal remanent magnetization (IRM), anhysteretic remanent magnetization (ARM), hard isothermal remanent magnetization (HIRM), and the ratio of susceptibility of ARM to $\chi\left(\chi_{\text {ARM }} / \chi\right)$ versus depth in core. The lithologic column is that shown in figure 5 . Shaded boxes indicate pollen zones. Dashed lines are aligned with lithologic contacts that have associated high values of $\chi_{\text {ARM }} / \chi$, indicative of single-domain ferrimagnetic grains. 
peaty sediment are low, except for two samples in the upper few centimeters of the core.

Correlations between $\chi$ and density and between HIRM and density (fig. 7) indicate that variations in these magnetic properties are due, in part, to variable dilution of magnetic lithic material by nonmagnetic organic matter. The correlations indicate that the density of organic matter (the $y$ inter- cepts on the plots) is between about 0.16 and $0.20 \mathrm{~g} \mathrm{~cm}^{-3}$. The maximum sample densities (about $1.4 \mathrm{~g} \mathrm{~cm}^{-3}$ ) are in lithic-rich samples that probably contain only a small percentage of organic matter. Assuming $1.4 \mathrm{~g} \mathrm{~cm}^{-3}$ to be the dry-bulk density of sediment containing only lithic material, the lithic content of the organic-rich sediment is seen to range from about 10 to 45 percent. Pollen zone 2 (fig. 8) has variable, but generally
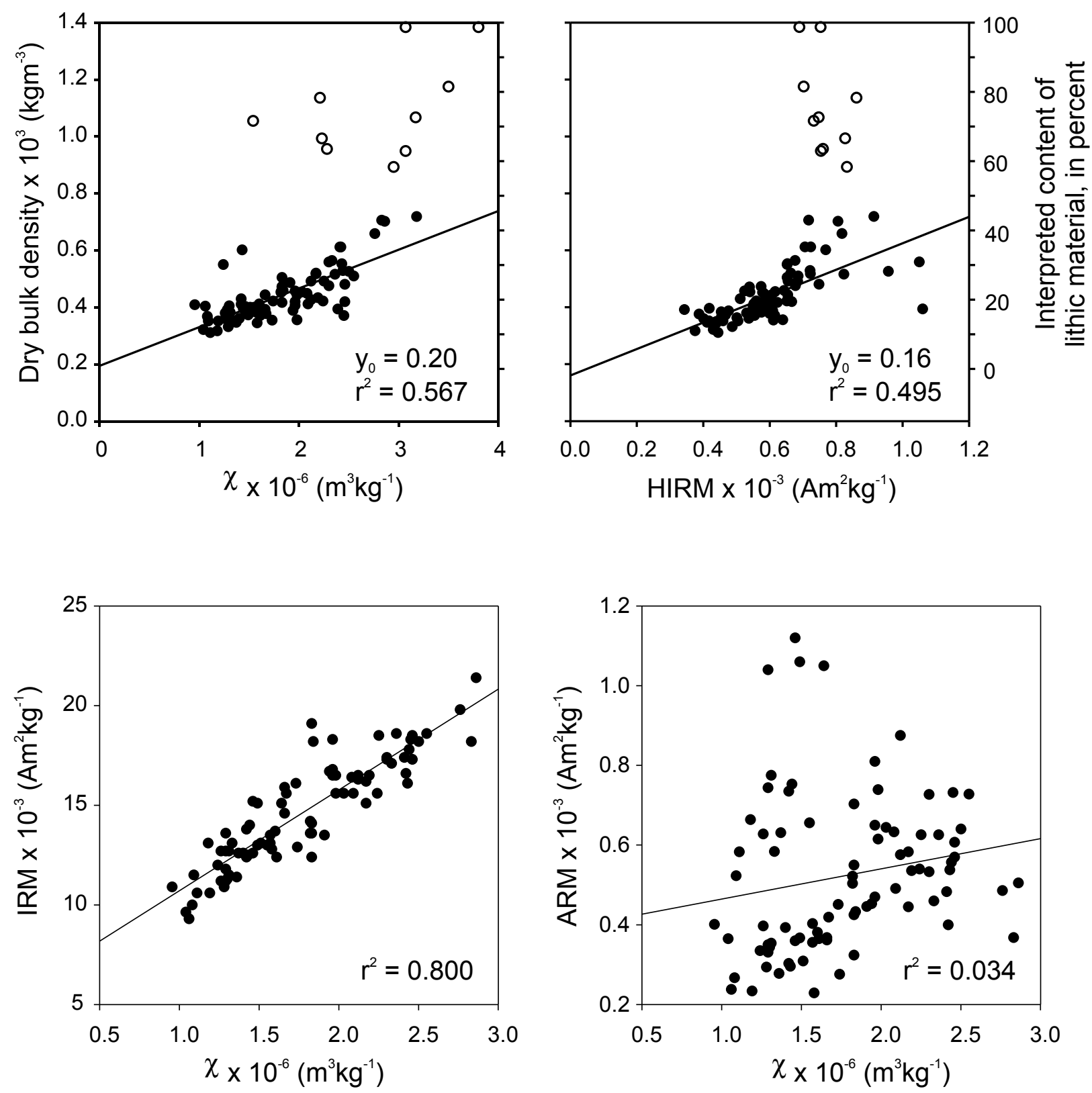

Figure 7. Plots of magnetic susceptibility $(\chi)$ and hard isothermal remanent magnetization (HIRM) versus density, and of $\chi$ versus isothermal remanent magnetization (IRM) and anhysteretic remanent magnetization (ARM). Solid symbols are for samples above $2.7 \mathrm{~m}$ core depth and were included in the linear regression. Open symbols are for samples below $2.7 \mathrm{~m}$ and were not included in the linear regression. A scale depicting the interpreted content of lithic material is shown on the right side of the upper plots. 


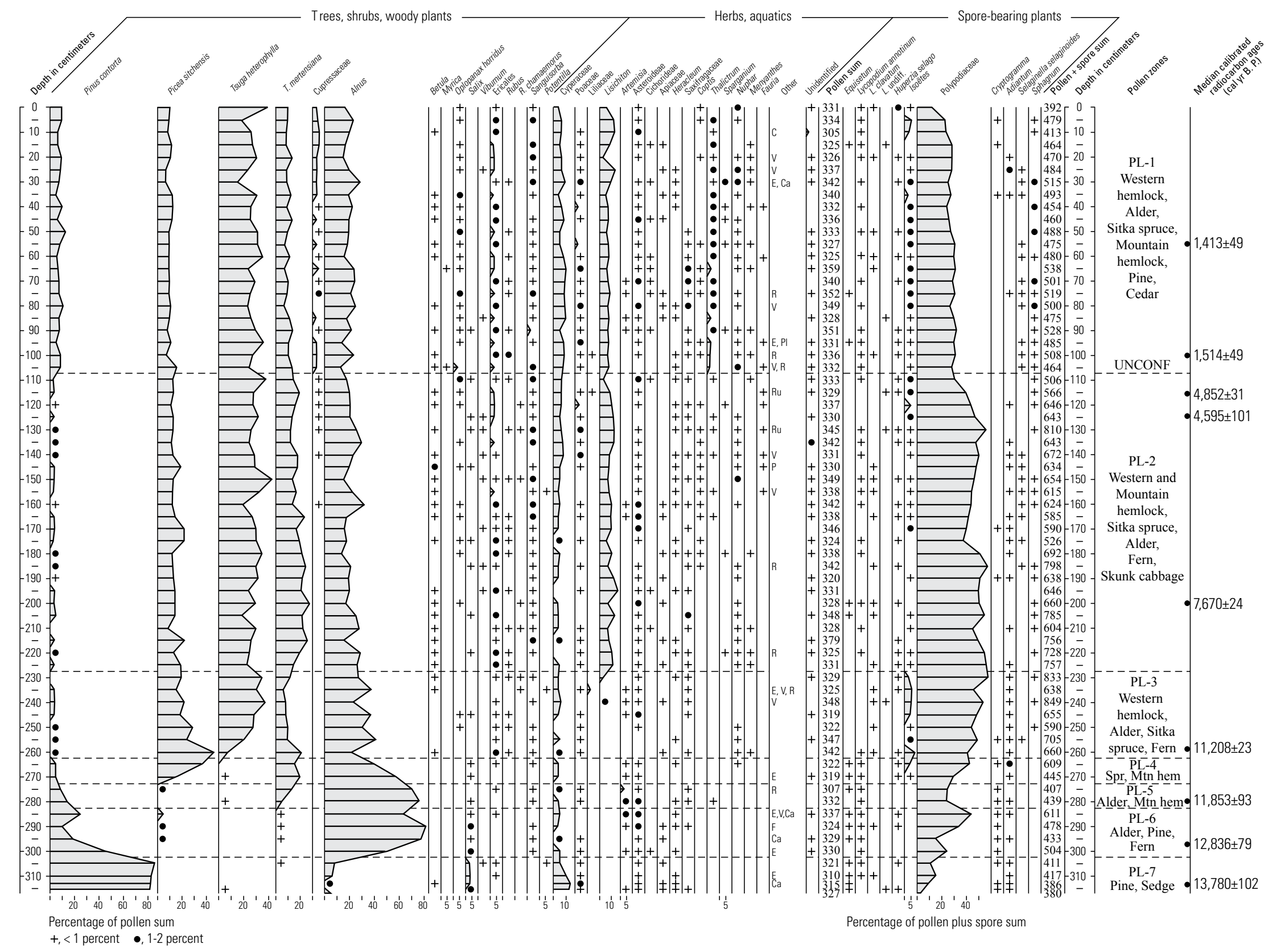

Figure 8. Pollen percentage diagram from Pass Lake, Prince of Wales Island, Alaska. Calibrated radiocarbon ages for samples from the Pass Lake core are shown in the right column. Additional information on the radiocarbon samples and dates is provided in table 2. 
higher content of lithic material than either pollen zones 1 or 3 , suggesting that production or transport of organic matter in the catchment may have been lower during this period.

Magnetic properties of the Pass Lake sediments are affected by factors other than the mixture of organic and lithic components. For the lithic-rich samples below $270 \mathrm{~cm}$, values of both magnetic susceptibility (MS) and HIRM are much lower than would be predicted by the linear correlations shown in figure 7. Either the lithic material in those samples has a different source than that in the overlying sediments, or detrital Fe-oxide minerals are more highly altered in the lithicrich portion of the section than in the overlying organic-rich sediments. Alteration of Fe-oxide minerals is considered to be the more likely of these options. The only likely nonlocal source of sediments that may have entered the lake early in its history is loess, but loess-derived sediments have not yet been recognized in the Pass Lake area. Alteration of Fe-oxide minerals preferentially destroys fine-grained magnetite (Rosenbaum and Reynolds, 2004) and is consistent with the observed values of $\chi_{\mathrm{ARM}} \chi$, which indicate that magnetic grain sizes of the lithic-rich samples are coarser than those in the organicrich material (fig. 6).

Above the basal, lithic-rich sediment, IRM and MS are strongly correlated, indicating that they are largely measures of ferromagnetic-mineral content (fig. 7). However, ARM and $\chi$ are uncorrelated. Inspection of figure 6 indicates that many of the peaks in $\chi_{\text {ARM }} \chi$ are the result of elevated ARM values and low $\chi$ values. This relation suggests that samples with high values of $\chi_{\mathrm{ARM}} / \chi$ contain some magnetically very finegrained (that is, single domained) ferrimagnetic mineral from a source unrelated to the detrital lithic material. It is plausible that such mineral grains are magnetosomes produced by magnetic bacteria (Oldfield, 1994), although confirmation of this would require imaging of grains with a transmission-electron microscope.

Regardless of their origin, the fine-grained ferrimagnets occur only in peaty sediment at, or a few centimeters above, contacts in the core (fig. 6). Based on available radiocarbon ages, one such contact at $110-\mathrm{cm}$ core depth is recognized as an unconformity, indicative of low lake level or subaerial exposure of the lake floor. This environment apparently was conducive to the formation or preservation of these small mineral grains. Other contacts with associated fine-grained ferrimagnets probably represent similar events at Pass Lake - low lake levels or subaerial exposure leading to the possible development of unconformities in the record. If so, the Pass Lake paleoenvironmental record may have more gaps than currently recognized based on calibrated radiocarbon ages from the core. Only the contact at $110-\mathrm{cm}$ core depth coincides with a pollen-zone boundary. Therefore, the hypothesized intervals of low lake levels or subaerial exposure of the lake floor may not have been the result of climate change; but local factors, such as presence or absence of beaver dams or log jams in the outlet stream may have repeatedly altered the lake level.

\section{Pollen Assemblage Zones from the Pass Lake Core}

The Pass Lake pollen and spore percentage diagram (fig. 8 ) is divided into seven pollen- and spore-assemblage zones. The zone boundaries were drawn by visual inspection where significant vegetation changes are inferred from major changes in percentages of key pollen and spore types. The pollen-spore assemblage zones from the Pass Lake core are described here from oldest to youngest.

Zone PL-7, Core interval 318-303 cm, 12,000-11,100 ${ }^{14} \mathrm{C}$ yr B.P. ( 13,800-12,960 yr B.P.) — Pollen assemblages are dominated by Pinus (79-83.5 percent), with Cyperaceae (4.4-12.1 percent), and Polypodiaceae-type fern spores (12.424.4 percent of pollen plus spore sum). Other taxa present in smaller amounts include Alnus (1.9-6.9 percent), Salix (1.2-2.9 percent), and several herbaceous taxa, including Poaceae (0.31.3 percent), Asteroideae (0.3-0.6 percent), Heracleum ( 0.3 percent), and other Apiaceae ( 0.3 percent).

Zone PL-6, Core interval $283-303 \mathrm{~cm}, \sim 10,200-11,100$ ${ }^{14} \mathrm{C}$ yr B.P. ( 11,900-12,960 yr B.P.) — Pollen assemblages are dominated by Alnus, which increases from 50 percent at the base of the zone to 80.9 percent at the top. Pinus percentages decline from 43.3 to 8.0 percent at the top of the zone. Polypodiaceae fern spores rise from 23.1 to 43.5 percent in this zone. Other taxa include Cyperaceae (1.2-4.7 percent) and minor amounts ( $<2$ percent) of Salix, Tsuga mertensiana, Sanguisorba, Poaceae, Artemisia, Asteroideae, Heracleum, and other Apiaceae.

Zone PL-5, Core interval 273-283 cm, 10,200-10,000 ${ }^{14}$ C yr B.P. ( 11,900-11,440 yr B.P.) — Pollen assemblages are dominated by Alnus (72.0-75.9 percent), with rising percentages of Tsuga mertensiana (3.9-11.4 percent) and declining percentages of Pinus pollen (12.3-7.2 percent). Polypodiaceae fern spores are also an important component of the assemblage (23.5-23.8 percent). Minor tree, shrub, and low woody plant taxa ( $<2$ percent) include Picea, Salix, Ericales and Sanguisorba. Herbaceous taxa ( $<3$ percent) include Cyperaceae, Poaceae, Artemisia, Asteroideae, Saxifragaceae, Thalictrum, and other Ranunculaceae.

Zone PL-4, Core interval $263-273 \mathrm{~cm}, \sim 10,000-9,850$ ${ }^{14} \mathrm{C}$ yr B.P. $(\sim 11,440-11,240$ yr B.P.) — Pollen assemblages are dominated by Alnus (42-59 percent), Tsuga mertensiana (14-20 percent), increasing percentages of Picea (13-35 percent), minor percentages of Pinus (2-4 percent), and fairly abundant Polypodiaceae fern spores (27-41 percent). Other shrub and woody taxa present in small amounts include Salix, Ericales, and Sanguisorba. Herbaceous taxa are present in low percentages and include Cyperaceae, Artemisia, Asteroideae, Heracleum, and Epilobium.

Zone PL-3, Core interval $228-263 \mathrm{~cm}, \sim 9850-8260{ }^{14} \mathrm{C}$ yr B.P. ( 11,240-9,250 yr B.P.) — Pollen assemblages are dominated by Tsuga heterophylla (5-37 percent), Alnus (21-42 percent), Picea (15-45 percent), Tsuga mertensiana (5-21 percent), and spores of Polypodiaceae (39-57 percent). Less abundant pollen types include Pinus, Cyperaceae, and spores 
of the aquatic plant Isoëtes. Shrubs and low woody taxa represented by pollen percentages of $<1$ percent include Ericales, Betula, Rubus, and Sanguisorba. Herbaceous pollen types include Artemisia, Asteroideae, Poaceae, Saxifragaceae, and the aquatic plant Nuphar.

Zone PL-2, Core interval 108-228 cm, 8,260-3,400 ${ }^{14} \mathrm{C}$ yr B.P. ( 9, 250-3, 640 yr B.P.) — Pollen assemblages are dominated by Tsuga heterophylla (17-41 percent), Tsuga mertensiana (10-26 percent), Alnus (15-32 percent), Picea (8-21 percent), and spores of Polypodiaceae ferns (31-56 percent). Shrub and woody taxa include Betula, Oplopanax, Salix, Viburnum, Ericales, Sanguisorba, and Rubus sp. Herbaceous taxa include Cyperaceae, Lisichiton, Asteroideae, Heracleum, other Apiaceae, Saxifragaceae, and Coptis. Aquatic taxa, such as Nuphar and Isoëtes, are represented in many samples within PL-2, but in low percentages.

Zone PL-1, Core interval 0-108 cm; 0-1,640 ${ }^{14} \mathrm{C}$ yr B.P. ( 0-1,530 yr B.P.)(or $\sim 1,440-1,640{ }^{14} C$ yr B.P.; $\sim 1,330-1,530$ $y r$ B.P.) - Pollen assemblages in this zone are dominated by arboreal pollen of Tsuga heterophylla (15-38 percent), Alnus (13-28 percent), Picea (7-15 percent), Tsuga mertensiana (6-14 percent), Pinus (5-12 percent), and Cupressaceae type (0-5 percent). Polypodiaceae spores are also moderately abundant (12-31 percent). Shrubs and low, woody plants represented by pollen in this zone include Ericales, Oplopanax horridus, Rubus, and Sanguisorba. The most abundant herbaceous pollen types represented include Cyperaceae and Lisichiton. Other herb pollen types represented consistently in PL-1 include Poaceae, Asteroideae, Cichorideae, Saxifragaceae, Thalictrum, Heracleum, and other Apiaceae, as well as aquatic plants, such as Nuphar, Menyanthes, and Sparganium. Spore types are dominated by Polypodiaceae fern spores, but there are low percentages of Isoëtes, Lycopodium annotinum, L. clavatum, Huperzia selago, Selaginella selaginoides, and Sphagnum moss spores.

\section{Interpretations of Vegetation and Climate History}

Deglaciation of the major fiords in southern southeastern Alaska and the Queen Charlotte Islands of northern British Columbia was probably mostly complete by $\sim 13,500{ }^{14} \mathrm{C}$ yr B.P. ( 15,700 yr B.P.; Mann, 1986; Barrie and Conway, 1999). In the interior of southern Prince of Wales Island, the final disappearance of local icecaps and stagnating ice in valleys may have taken place somewhat later. The lowermost $5 \mathrm{~cm}$ of the Pass Lake core contains no pollen, suggesting that vegetation was absent or very sparse in the area at the time those mineral-rich sediments were deposited, perhaps soon after local deglaciation.

At Pass Lake, the pollen record begins $\sim 11,900{ }^{14} \mathrm{C}$ yr B.P. $(\sim 13,700 \mathrm{yr}$ B.P.), when the first recorded vegetation to develop in the area was pine woodland with shrubs (fig. 9) (willows and a few scattered alders), sedges, herbs, and ferns.
The pine species involved in this rapid colonization was presumably shore pine (Pinus contorta subsp. contorta), the only subspecies of pine that grows today in the Alexander Archipelago. This pioneering vegetation of pine woodland has been documented in several sites in southeastern Alaska and coastal British Columbia (Heusser, 1960, 1965, 1985; Lacourse and Mathewes, 2005; Lacourse and others, 2005; Ager, 2007). Stomatal cells derived from decomposed pine needles found in sediments recovered offshore near the Queen Charlotte Islands in northern coastal British Columbia indicate the presence of pine in that area (immediately south of Prince of Wales Island) by $\sim 13,000{ }^{14} \mathrm{C}$ yr B.P. $(\sim 15,140$ yr B.P.; Lacourse and others, 2005). Pollen evidence from Heceta Island suggests that pines may have been present in the southwestern Alexander Archipelago as early as $13,800{ }^{14} \mathrm{C}$ yr B.P. $(\sim 16,070$ yr B.P.; Ager, 2007).

Beginning $\sim 11,000{ }^{14} \mathrm{C}$ yr B.P. $(\sim 12,875$ yr B.P.), the pine population began a rapid decline in the Pass Lake area, a decline that coincided with a rapid expansion of alders. Alders persisted as the dominant woody plant until $\sim 10,000{ }^{14} \mathrm{C} \mathrm{yr}$ B.P. $(\sim 11,440 \mathrm{yr}$ B.P.). The decline of pines and the alder expansion coincides with the Younger Dryas climate event that has been interpreted to represent a colder, drier climate in the North Pacific region (Hansen and Engstrom, 1996; Mathewes, 1993). Several of Heusser's pollen records from southeastern Alaska and northern British Columbia (1960) begin with a pine pollen zone that is replaced by expanding percentages of alder and spruce pollen. The lack of radiocarbon ages from most of Heusser's sites, however, precludes certain correlation of the pine decline with Younger Dryas cooling at all localities, however. The vegetation response to Younger Dryas cooling varies from site to site and therefore remains unclear in this region.

Climatic warming that began in the early Holocene (Heusser and others, 1985) coincides with the rise of mountain hemlock and is followed soon thereafter by Sitka spruce colonization $\sim 9,900{ }^{14} \mathrm{C}$ yr B.P. $(\sim 11,280$ yr B.P.) in the Pass Lake record. Western hemlock pollen appears in the Pass Lake pollen record by $\sim 9,800{ }^{14} \mathrm{C}$ yr B.P. $(\sim 11,220 \mathrm{yr}$ B.P.). Western hemlock trees are most commonly found at low to middle elevations in southeastern Alaska, where they constitute the dominant tree species in the coastal forests (DeMeo and others, 1992). Some western hemlock may grow near Pass Lake today, but none were observed there during our visits to the area during the 1999 summer field season. The abundant western hemlock pollen seen in the Pass Lake core after $\sim 9,800{ }^{14} \mathrm{C}$ yr B.P. $(\sim 11,220$ yr B.P.) is probably a result of wind transport of that pollen type from lower altitude forests elsewhere on Prince of Wales Island. Wind transport of western hemlock pollen tens of kilometers beyond the boundaries of the species' modern distribution has been documented at White Pass, on the northern British Columbia-southeastern Alaska border north of Lynn Canal (fig. 1; Cwynar, 1993).

Once established during the early Holocene, Sitka spruce and mountain hemlock forest and alder thickets covered 


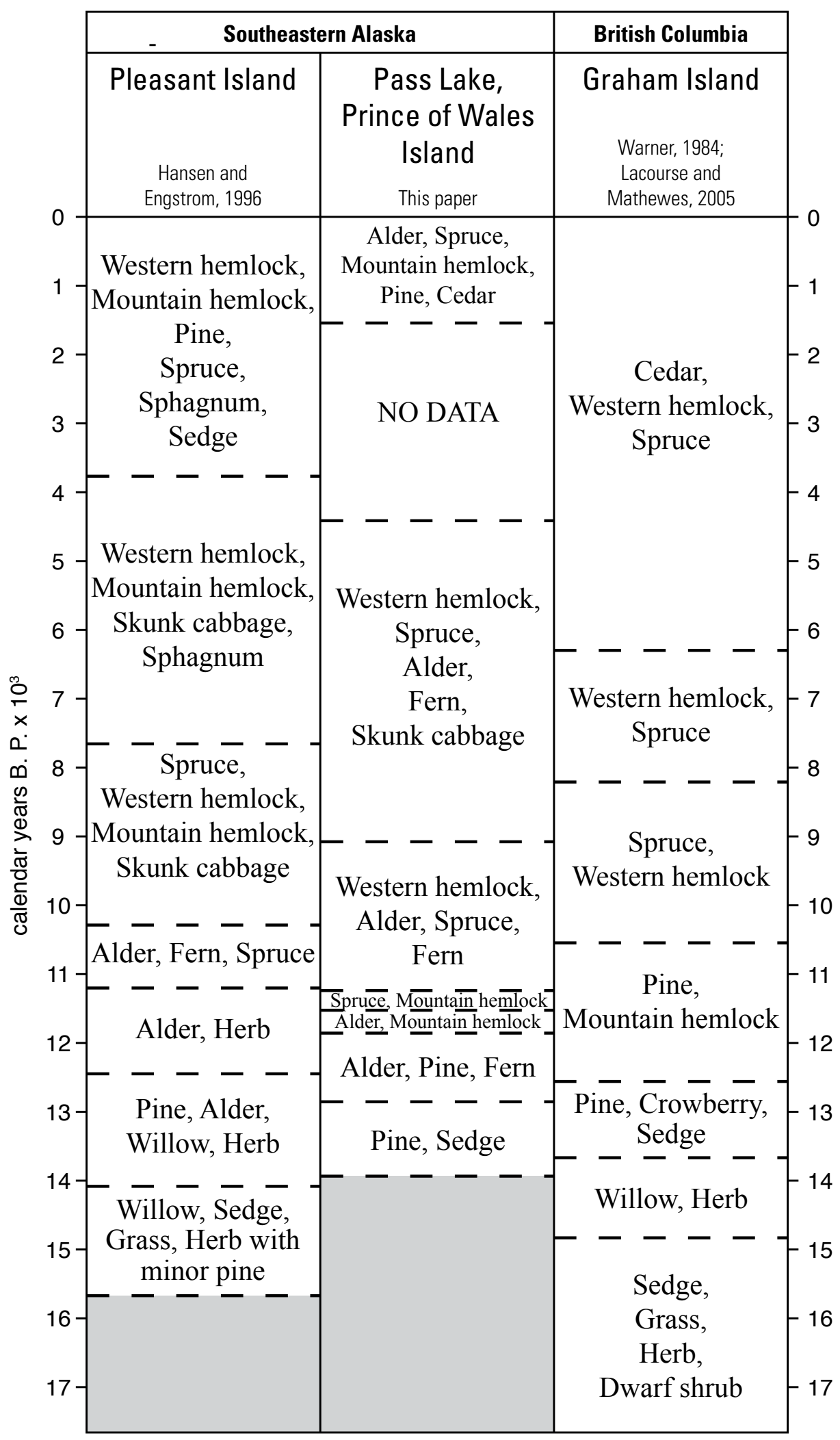

Figure 9. Chart comparing dated vegetation histories from southeast Alaska and the Queen Charlotte Islands (Haida Gwaii), northern coastal British Columbia. See figures 1 and 2 for site locations. 
most of the Pass Lake area until $\sim 4,300{ }^{14} \mathrm{C}$ yr B.P. $(\sim 4,850$ yr B.P.). Between $\sim 4,300$ and $1,600{ }^{14} \mathrm{C}$ yr B.P. $(\sim 4,850$ and 1,490 yr B.P.), an interval of nondeposition or erosion occurred at the coring site. Lake-level changes may have subaerially exposed much of the shallow lake floor during this time. The pollen record of the past $\sim 1,600{ }^{14} \mathrm{C}$ yr B.P. ( 1,490 yr B.P.) indicates that the vegetation of the Pass Lake area differed from that of the preceding interval, $\sim 4,300-9,500{ }^{14} \mathrm{C}$ yr B.P. ( 4850-10,760 yr B.P.), when Sitka spruce-mountain hemlock-alder woodland predominated. In contrast, during the past $\sim 1600{ }^{14} \mathrm{C}$ yr B.P., the Pass Lake area's vegetation had higher percentages of pine and cedar pollen, while percentages of Sitka spruce and mountain hemlock pollen declined slightly. The cedar pollen is probably derived from yellow cedar, a tree species that grows near Pass Lake today. These changes in the pollen assemblages may reflect expanding muskeg vegetation in the area. Shore pine, yellow cedar, and mountain hemlock trees can tolerate conditions in muskeg peatlands (high water tables, acidic soils, low nutrient availability), and those tree species commonly occur in muskeg sites in the Pass Lake area. Sitka spruce is more common in sites with better drainage.

Neoglacial cooling and a shift to wetter climates in coastal regions of the Gulf of Alaska during the late Holocene has been documented from past glacial advances and reconstructed temperature trends. This climate change may have resulted in lower treelines and an expansion of lightly forested muskeg peatlands at the expense of dense lowland forest (Heusser, 1985; Heusser and others, 1985; Hansen and Engstrom, 1996; Pellatt and Mathewes, 1997; Clague and others, 2004; Turunen and Turunen, 2003).

Archeological evidence indicates that humans were clearly present in the Prince of Wales Island area as early as $9,200{ }^{14} \mathrm{C}$ yr B.P. $(\sim 10,340$ yr B.P.). A dated bone artifact suggests that humans probably were present earlier, $\sim 10,400$ ${ }^{14}$ C yr B.P. $(\sim 12,270$ yr B.P.; Dixon, 1999, 2001). If the older radiocarbon age is correct, it indicates that humans were apparently present in southeastern Alaska during the transition from the cold, relatively dry climate of the Younger Dryas ( $\sim 11,100-10,100{ }^{14} \mathrm{C}$ yr B.P.; $\sim 12,900-11,600$ yr B.P.; Alley and others, 1993) to the early Holocene warm interval documented for the Gulf of Alaska coastal region (Heusser and others, 1985). During that time, a shift in vegetation occurred from pine woodland and alder shrub communities to a more complex vegetation that incorporated additional tree species, such as mountain hemlock, Sitka spruce, and then western hemlock during the early Holocene.

Early postglacial mammal faunas documented from vertebrate-fossil assemblages preserved in caves (Heaton and Grady, 2003), shifted from sea ice-, tundra-, and woodlandadapted species, such as caribou, arctic fox, red fox, ring seal, and brown bear, to forest-adapted species such as Sitka blacktailed deer, river otter, and long-tailed voles, during the early Holocene. Black bear were present during both late glacial time and during the Holocene (Heaton and Grady, 2003).

\section{Summary}

Pollen evidence from the Pass Lake core indicates that the earliest vegetation to develop in the area soon after deglaciation was pine woodland with willows, sedges, and herbs $(\sim 13,715$ to $12,875 \mathrm{yr}$ B.P.). At that time, the pine population declined, and alder thickets with ferns became the dominant local vegetation. The pine decline may have been caused by the Younger Dryas cold interval ( 12,900-11,440 yr B.P.) but it is not yet clear if there was a regional vegetation response to that cooling event. At the beginning of the Holocene, alder thickets diminished in extent ( 11,440 yr B.P.) as the climate began to warm and as conifer forest and muskeg communities began to colonize the area. However, alder thickets remained significant elements of the vegetation throughout the Holocene in the Pass Lake area. Alders probably occupied streambanks, avalanche scars, and upper slopes of the nearby valley walls. During the early Holocene, rapid vegetation changes occurred as the pine population continued to decline, while mountain hemlock, then Sitka spruce and mountain hemlock, colonized the valley floor and lower valley slopes. Western hemlock is well represented in the pollen record in the Pass Lake core after $\sim 11,220 \mathrm{yr}$ B.P., but it does not appear to grow in the vicinity of the lake today. Its pollen is apparently transported to the Pass Lake area by wind from western hemlock populations growing in abundance elsewhere on Prince of Wales Island.

Expansion of muskeg vegetation near Pass Lake during the late Holocene may have resulted from paludification of soils, as accumulating peat deposits and developing hardpan soils impeded drainage and created wet, organic soils poor in nutrients, conditions unfavorable for tree growth on parts of the valley floor (Turunen and Turunen, 2003; Ugolini and Mann, 1979). Peat accumulation and the expansion of muskeg vegetation would have been favored by cooler, wetter climates of the late Holocene.

Our study of the magnetic properties of peat and sediments in the Pass Lake core suggests that there may be several unconformities in the core, only one of which was recognized by radiocarbon dating and pollen analysis. The unconformities probably developed during intervals when lake level was low, possibly exposing the lake floor to subaerial conditions.

\section{Acknowledgments}

The authors express their appreciation to the U.S. Forest Service for the cooperation, collaboration, and logistics support received during the 1998, 1999, and 2000 field seasons in Tongass National Forest. Forest Service scientists Jim Baichtal, Terry Fifield, Michael Shephard, Terry Brock, and Dennis Landwehr participated in several of our field investigations. The authors also wish to thank Jossh Beann (USGS, Denver), and R. Lawrence Phillips (USGS, Menlo Park) for assisting with the coring operations at Pass Lake in 1999. Phillips also 
contributed to the description of core lithology (fig. 5). John McGeehin and his laboratory staff prepared our samples for Accelerator Mass Spectrometry (AMS) radiocarbon dating. We also acknowledge Rich Reynolds and Dan Muhs for their reviews of this manuscript; their constructive suggestions greatly improved our paper. The USGS Earth Surface Dynamics Program funded this research.

\section{References}

Ackerman, R.E., 1996, Ground Hog Bay, Site 2, in West, F.H., ed., American beginnings - The prehistory and palaeoecology of Beringia: Chicago, University of Chicago Press, p. 424-430.

Ager, T.A., 2007, Vegetation development on Heceta Island, southeastern Alaska during the Late Glacial and Holocene: Geological Society of America Abstracts with Programs, v. 39, no. 4, p. 17.

Alaback, P., and Pojar, J., 1997, Vegetation from ridgetop to seashore, in Schoonmaker, P.K., von Hagen, B., and Wolf, E.C., eds., The rain forests of home: Washington, D.C., Island Press, p. 69-87.

Alley, R.B., Meese, D.A., Schuman, A.J., Gow, A.J., Taylor, K.C., Grootes, P.M., White, J.W.C., Ram, M., Waddington, E.D., Mayewski, P., and Zielinski, G.A. 1993, Abrupt accumulation increase at the Younger Dryas termination in the GISP2 ice core: Nature, v. 362, p. 527-529.

Baichtal, J., Streveler, G., and Fifield, T., 1997, The geological, glacial and cultural history of southern southeast, in Rennick, P., ed., Alaska's Southern Panhandle: Alaska Geographic, v. 24, no. 1, p. 6-31.

Barrie, J.V., and Conway, K.W., 1999, Late Quaternary glaciation and postglacial stratigraphy of the northern Pacific margin of Canada: Quaternary Research, v. 51, p. 113-123.

Barrie, J.V., Conway, K.W., Mathewes, R.W., Josenhans, H.W., and Johns, M.J., 1993, Submerged Late Quaternary terrestrial deposits and paleoenvironment of northern Hecate Strait, British Columbia continental shelf, Canada: Quaternary International, v. 20, p.123-129.

Carrara, P.E., Ager, T.A., and Baichtal, J.F., 2007, Possible refugia in the Alexander Archipelago of southeastern Alaska during the late Wisconsin glaciation: Canadian Journal of Earth Sciences, v. 44, p. 229-244.

Carrara, P.E., Ager. T.A., Baichtal, J.F., and VanSistine, P.D., 2003, Map of glacial limits and possible glacial refugia in the southern Alexander Archipelago, Alaska, during the late Wisconsin glaciation: U.S. Geological Survey Miscellaneous Field Studies Map MF-2424, scale 1:500,000, with text.

Clague, J.J., Mathewes, R.W., and Ager, T.A., 2004, Environments of northwestern North America before the Last Glacial Maximum, in Madsen, D.B., ed., Entering America-Northeast Asia and Beringia before the Last
Glacial Maximum: Salt Lake City, University of Utah Press, p. 63-94.

Cwynar, L.C., 1990, A late Quaternary vegetation history of Lily Lake, Chilkat Peninsula, southeast Alaska: Canadian Journal of Botany, v. 68, p. 1106-1112.

Cwynar, L.C., 1993, The abundance of exotic western hemlock pollen at Waterdevil Lake, White Pass, northern British Columbia - a preliminary analysis: Review of Palaeobotany and Palynology, v. 79, p. 113-119.

Dachnowski-Stokes, A.P., 1941, Peat Resources in Alaska: U.S. Department of Agriculture Technical Bulletin no. 769, 84 p.

Davis, S.D. 1996, Hidden Falls, in West, F.H., ed., American beginnings - The prehistory and paleoecology of Beringia: Chicago, University of Chicago Press, p. 413-424.

DeMeo, T., Martin, J., and West, R.A., 1992, Forest plant association management guide, Ketchikan Area, Tongass National Forest: U.S. Dept. of Agriculture Forest Service, Alaska Region Report R10-MB-210, 405 p.

Dixon, E.J., 1999, Bones, boats and bison-Archeology and the first colonization of western North America: Albuquerque, University of New Mexico Press, 322 p.

Dixon, E.J., 2001, Human colonization of the AmericasTiming, technology and process: Quaternary Science Reviews, v. 20, p. 277-299.

Dixon, E.J., Heaton, T.H., Fifield, T.E., Hamilton, T.D., Putnam, D.E., and Grady, F., 1997, Late Quaternary regional geoarchaeology of southeast Alaska karst-a progress report: Geoarchaeology, v. 12, p. 689-712.

Doher, L.I., 1980, Palynomorph preparation procedures currently used in paleontology and stratigraphy laboratories: U.S. Geological Survey Circular 830, 29 p.

Dunlop, D., and Özdemir, Ö., 1997, Rock magnetism-fundamentals and frontiers: New York, Cambridge University Press, 573 p.

Engstrom, D.R., Hansen, B.C.S., and Wright, H.E., Jr., 1990, A possible Younger Dryas record in southeastern Alaska: Science, v. 250, p. 1383-1385.

Evans, M.E., and Heller, F., 2003, Environmental magnetism: New York, Academic Press, 299 p.

Fairbanks, R.G., Mortlock, R.A., Tzu-Chien, C., Cao, L., Kaplan, A., Giulderson, T.P., Fairbanks, T.W., Bloom, A.L., Grootes, P.M., and Nadeau, M.J., 2005, Marine radiocarbon calibration curve spanning 0 to 50,000 years B.P. based on paired ${ }^{230} \mathrm{Th} /{ }^{234} \mathrm{U} /{ }^{238} \mathrm{U}$ and ${ }^{14} \mathrm{C}$ dates on pristine corals: Quaternary Science Reviews, v. 24, p. 1781-1796.

Hansen, B.C.S., and Engstrom, D.R., 1996, Vegetation history of Pleasant Island, southeastern Alaska, since 13,000 B.P.: Quaternary Research, v. 46, p. 161-175.

Harris, A.S., 1969, Subalpine fir on Harris Ridge near Hollis, Prince of Wales Island, Alaska: Northwest Science, v. 39, p. 123-128.

Heaton, T.H., and Grady, F., 2003, The late Wisconsin ver- 
tebrate history of Prince of Wales Island, Southeast Alaska, in Schubert, B.W., Mead, J.I., and Graham, R.W., eds., Ice Age cave faunas of North America: Bloomington, Indiana University Press, p. 17-53.

Heaton, T.H., Talbot, S.L., and Shields, G.F., 1996, An ice age refugium for large mammals in the Alexander Archipelago, southeastern Alaska: Quaternary Research, v. 46, p. 186-192.

Heusser, C.J., 1952, Pollen profiles from southeastern Alaska: Ecological Monographs, v. 22, p. 331-352.

Heusser, C.J., 1960, Late Pleistocene Environments of North Pacific North America: New York, American Geographical Society, Special Publication 35, 308 p.

Heusser, C.J., 1965, A Pleistocene phytogeographic sketch of the Pacific Northwest and Alaska, in Wright, H.E., Jr., and Frey, D.G., eds., The Quaternary of the United States: Princeton, Princeton University Press, p. 469-483.

Heusser, C.J., 1985, Quaternary pollen records from the Pacific Northwest coast-Aleutians to the Oregon-California boundary, in Bryant, V.M., Jr., and Holloway, R.G., eds., Pollen records of Late-Quaternary North American sediments: Dallas, American Association of Stratigraphic Palynologists Foundation, p. 141-165.

Heusser, C.J., 1989, North Pacific coastal refugia - the Queen Charlotte Islands in perspective, in Scudder, G.G.E., and Gessler, N., eds., The outer shores: Skidegate, British Columbia, Queen Charlotte Island Museum, p. 91-106.

Heusser, C.J., Heusser, L.E., and Peteet, D.M., 1985, LateQuaternary climatic change on the American North Pacific coast: Nature, v. 315, p. 485-487.

Hultén, E., 1968, Vascular flora of Alaska and neighboring Territories: Stanford, Stanford University Press, 1008 p.

Jaques, D.R., 1973, Reconnaissance botany of alpine ecosystems on Prince of Wales Island, southeast Alaska: Eugene, University of Oregon, unpublished master's thesis, $133 \mathrm{p}$.

Karlstrom, T.N.V., 1964, Quaternary geology of the Kenai Lowland and glacial history of the Cook Inlet region, Alaska: U.S. Geological Survey Professional Paper 443, 69 p., 6 sheets, various scales.

Kaufman, D.S., and Manley, W.F., 2004, Pleistocene maximum and Late Wisconsin glacier extents across Alaska, U.S.A., in Ehlers, J., and Gibbard, P.L., eds., Quaternary glaciations - Extent and chronology, Part II, North America: Developments in Quaternary Science, v. 2. Amsterdam, Elsevier Press, p. 9-27.

King, J.W., and Channel, J.E.T., 1991, Sedimentary magnetism, environmental magnetism, and magnetostratigraphy: Reviews of Geophysics, v. 29, supplement, p. 358-370.

Lacourse, T., and Mathewes, R.W., 2005, Terrestrial paleoecology of Haida Gwaii and the continental shelf, in Fedje, D.W., and Mathewes, R.W. eds., Haida Gwaii:
Human History and Environment from the Time of Loon to the Time of the Iron People. Vancouver, Pacific Rim Archaeology Series, University of British Columbia Press, p. 38-58.

Lacourse, T., Mathewes, R.W., and Fedje, D.W., 2005, Lateglacial vegetation dynamics of the Queen Charlotte Islands and adjacent continental shelf, British Columbia, Canada: Palaeogeography, Palaeoclimatology, Palaeoecology, v. 226, p. 36-57.

Leslie, L.D., 1989, Alaska Climate Summaries: Anchorage, Alaska Climate Center Technical Note No. 5, 478 p.

Mann, D.H., 1986, Wisconsin and Holocene glaciation of southeast Alaska, in Hamilton, T.D., Reed, K.M., and Thorson, R.M., eds., Glaciation in Alaska: Anchorage, Alaska Geological Society, p. 237-265.

Mathewes, R.W., 1993, Evidence for Younger Dryas age cooling on the North Pacific coast of America: Quaternary Science Reviews, v. 12, p. 321-331.

Mathewes, R.W., Heusser, L.E., and Patterson, R.T., 1993, Evidence for a Younger Dryas-like cooling event in the British Columbia coast: Geology, v. 21, p. 101-104.

Moriya, K., 1978, Flora and palynomorphs of Alaska: Tokyo, Kodansha Publishing Co., 366 p.

Muller, M.C., 1982, A preliminary checklist of the vascular plants of southeastern Alaska: Wildlife and Fisheries Habitat Management Notes, U.S. Dept. of Agriculture Forest Service, Alaska Region Admin. Doc. no. 112, 32 p.

Neiland, B.J., 1971, The forest-bog complex of southeast Alaska: Vegetatio, v. 22, p. 1-64.

Nowacki, G., Shephard, M., Krosse, P., Pawuk, W., Fisher, G., Baichtal, J., Brew, D., Kissinger, E., and Brock, T., 2001, Ecological subsections of Southeast Alaska and neighboring areas of Canada: U.S. Dept. of Agriculture Forest Service, Alaska Region, Technical Publication no. R10-TP-75, $306 \mathrm{p}$.

Oldfield, F., 1994, Toward discrimination of fine-grained ferromagnets by magnetic measurements in lakeand nearshore sediments: Journal of Geophysical Research, v. 99, p. 9045-9050.

Østrem, G., Haakensen, N., and Eriksson, T., 1981, The glaciation level in southern Alaska: Geografiska Annaler, v. 63A, 3-4, p. 251-260.

Pellatt, M.G., and Mathewes, R.W., 1997, Holocene treeline and climate change on the Queen Charlotte Islands, Canada: Quaternary Research, v. 48, p. 88-99.

Peteet, D.M., 1986, Modern pollen rain and vegetational history of the Malaspina Glacier District, Alaska: Quaternary Research, v. 25, p. 100-120.

Pojar, A., and MacKinnon, A., eds., 1994, Plants of the Pacific Northwest Coast: Washington, Oregon, British Columbia and Alaska: Redmond, Washington, Lone Pine Publishing, $528 \mathrm{p}$.

Reger, R.D., Sturmann, A.G., Berg, E.E., and Burns, P.A.C., 2008, A Guide to the Late Quaternary History of Northern and Western Kenai Peninsula, Alaska: 
Guidebook 8, State of Alaska Department of Natural Resources, Division of Geological and Geophysical Surveys, $112 \mathrm{p}$.

Rosenbaum, J.G., and Reynolds, R.L., 2004, Basis for paleoenvironmental interpretation of magnetic properties of sediment from Upper Klamath Lake (Oregon) - effects of weathering and mineralogical sorting: Journal of Paleolimnology, v. 31, p. 253-265.

Sainsbury, C.L., 1961, Geology of part of the Craig C-2 Quadrangle and adjoining areas, Prince of Wales Island, Alaska: U.S. Geological Survey Bulletin 1058H, p. 299-362.

Schmoll, H.R., Yehle, L.A., and Updike, R.G., 1999, Summary of Quaternary geology of the Municipality of Anchorage, Alaska: Quaternary International, v. 60, p. 3-36.

Swanston, D.N., 1969, A Late-Pleistocene glacial sequence from Prince of Wales Island, Alaska: Arctic, v. 22, p.
25-33.

Thompson, R., and Oldfield, F., 1986, Environmental magnetism: London, Allen and Unwin, $227 \mathrm{p}$.

Turunen, C. and Turunen, J., 2003, Development history and carbon accumulation of a slope bog in oceanic British Columbia, Canada: The Holocene, v. 13, 225-238.

Ugolini, F.C., and Mann, D.H., 1979. Biopedological origin of peatlands in southeast Alaska: Nature, v.28, p. 20652070

Verosub, K.L., and Roberts, A.P., 1986, Environmental magnetism - past, present and future: Journal of Geophysical Research, v. 100, p. 2175-2192.

Viereck, L,A., and Little, E.L., Jr., 1972, Alaska trees and shrubs: U.S. Department of Agriculture Forest Service Handbook no. 410, 265 p.

Worley, I.A., and Jaques, D., 1973, Subalpine fir (Abies lasiocarpa) in coastal western North America: Northwest Science, v. 47, p. 265-273. 
